\title{
IMPACT OF E-RECRUITMENT ON THE EFFECTIVENESS OF HUMAN RESOURCE DEPARTMENT IN PRIVATE HEIS IN PAKISTAN
}

\section{Irfan Ali Kubar', Ume Sumayya ${ }^{1 *}$; Ume Amen², and Muhammad Mubeen ${ }^{1}$}

\begin{abstract}
This study aims to expound on the concept of "E-Recruitment" and its impact on the "HR department effectiveness" in the private higher education institutions of Karachi, Pakistan. The core objectives of the research study are to determine the level of effectiveness and relationship between E-Recruitment and the HR department of private HEI's of Karachi. A worklist can be found on industrial sectors, service sectors in the context of e-recruitment, but the research gap on educational institutions particularly Private HEI's is still there. An in-depth literature review is discussed. The research methodology briefs that, this study was both an Explanatory and Exploratory design in nature. 2 selfdeveloped questionnaires were utilized. Using SPSS version 25.0, the researchers performed several tests including descriptive statistics, reliability test, KMO, Bartlett's test, Pearson Correlation, and Multiple Regression tests. The results have proved that there is a strong positive relationship between independent and dependent variables and the relationship between them is accepted at a 5\% significance level. Also, it was evidenced from interviews that E-recruitment is a cost-beneficial method, has a greater geographical reach, shortened recruitment procedures, provides reliability in the recruitment procedure, and also facilitates the selection process of the HR department.
\end{abstract}

Keywords: E-Recruitment; Human Resource Department; Private HEIs.

\section{INTRODUCTION}

In recent times of information technology and the spread of the Covid-19 contagion has completely altered the nature of human resource staffing and the actions higher education

\footnotetext{
${ }^{1}$ Faculty of Business Administration, IQRA University, Karachi, Sindh, Pakistan.

${ }^{2}$ Institute of Business and Health Management, Dow University of Management Sciences, Karachi, Pakistan.

* Corresponding author: ume sumayya@hotmail.com
} 
institutions consider regarding the hiring process in Pakistan, particularly in private universities of Karachi. E-Recruitment is the process of hiring human resources by utilizing sources of eRecruitment with the help of the internet. Similarly, HR departments are the backbone of any institution either private or public, because this department is concerned with "bringing bestfit individuals into the institutions". Utilizing the Internet to attain an E-recruitment goal not only increases the productivity of the university but also saves time and wealth. Private Sectors especially HEI's taken into consideration for this research study because these are Pakistan's fastest expanding businesses and it is normally accepted that the private institutions working well in Pakistan, has reputable Human resources departments that prefer to use digital technology to nurture the recruitment actions, therefore, it is just realistic to measure the feasibility of this technology through the example of Karachi, Pakistan's Private HEI's. Growing Internet use in all walks of life serves as a demand for lots of private and mostly technical tasks to be accomplished. Internet technology has been accessible ever since the 1990s in Pakistan. Growth figures for Internet use in Pakistan indicate that Internet consumers reached equal to 22 million in 2013, in which 4.3 million consumers use high-speed Internet (Attaa, 2009). The details suggest that the utilization of digital technology in Pakistan is increasing very fast. Many institutions particularly private sectors including Industrial sectors, Service sectors, and Higher educational institutions particularly "Private Universities" are penetrating the ways to be more expandable, ground-breaking, experienced, and strategic to execute responsibilities effectively.

Internationalism, technology, and situations like COVID-19 moved institutions towards an Erecruitment strategy for the online staffing process to get the best-fit workforce. In realism workforce of any institution serves as an inspiration that shifts the entire institution on the right track. "Recruitment is described by (Breaugh \& Strake, 2000) as "Practices and techniques did by the company for the essential intention of finding out and recruiting new workers". Kapse et al., (2012) stated that "E-Recruitment is the utilization of innovation to help the recruitment function. The human resource attributes in internet technologies are known as the "HRIS" acronym of Human Resource Information System and the "E-HRM" acronym of Electronic Human Resource Management System DeSanctis (1986). "Human resource management covers all aspects of how individuals are utilized and overseen in institutions, as indicated by Armstrong (2010). HRM is seen by (Compton et al. 2009, p.2) as "Workers are related to other resources such as monetary assets and technology as it must be effectively administered to make sure the best performance for the entire institutions." E-recruitment can be divided into 
two widely used sources i.e. Institution's Official website for the e-recruitment process, it incorporates "Career Webpages" where candidates can log in for current job opportunities and another is "Online Job boards" such as Rozee.pk, Indeed.pk and so on for posting job advertisements where prospective employees can meet with opportunities provided by several employers recognized by the (CIPD, 2015).

In the context of Pakistan, many private universities are utilizing their own official website "career webpage" to hire best-fit candidates with the given electronic job descriptions. In which NUST all campuses use their career portals, Aga khan currently uses e-recruitment method for staff positions only, IBA Karachi uses IBA-Job portal/HRMS software to hire candidates, FAST NUCES use its respective Job Application System, Habib University has effective career webpage, LinkedIn Account where they offered various HU career jobs in three domains such as administrative jobs, academic support, and faculty positions then applicants need to apply in their academic domain. Ziauddin University has its respective job portal and LinkedIn Account and Barrett Hodgson University Karachi has a valuable career webpage, and they use the online job boards method where they post a vacant job description and provide an online application link and so on (Imam \& Javed, 2019; Malik \& Mujtaba, 2018).

\section{PROBLEM STATEMENT}

In the present research, the researcher investigates the subject i.e. e-Recruitment. Due to the sudden occurrence of COVID-19, Educational Institutions are looking for difficulties in attracting capable aspirants as the main part of the institution's continued existence lies in the hands of their keynote workers particularly the HR Dept. The impact of E-recruitment is not properly analyzed in private higher education institutions of Pakistan yet; however, the use of e-recruitment exists in many private universities in Pakistan as aforementioned in the introduction.

A work-list can be found on E-recruitment as cited below; Malik \& Mujtaba (2018) conducted on the subject E-Recruitment, in BZU Multan, Pakistan for his Dissertation requirement in the context of Private Companies HR Department of Pakistan. Another was conducted on MNCs of Bangladesh (Mindia \& Kazim-ul-Hoque, 2018) and an additional one was conducted in Hyderabad region Sindh, Pakistan on service sectors Imam \& Jawed (2019). Therefore, it is needed to study this research gap that how the Private Universities recruit administrative positions, academic support staff, and academic positions such as lecturers, Professors, etc. via institution's official websites and outsourcing job boards like Rozee.pk and how effectively 
this method is utilized by the HR department in the context of all Private Higher Education Institutions (HEI's) of Karachi, Pakistan.

\section{RESEARCH OBJECTIVES}

1. To determine the level of effectiveness of the Human Resources Department in terms of ERecruitment in Private HEI's of Karachi, Pakistan.

2. To identify measures that the HR management has put in place to tackle the E-recruitment challenges in Private HEI's of Karachi, Pakistan.

3. To determine the relationship between E-Recruitment and Human Resources Department in Private HEI's of Karachi, Pakistan.

\section{SIGNIFICANCE OF THE STUDY}

The research study would provide reliable information to policymakers in the Ministry of Education of Pakistan, Local Government, Institutions Rectors, and Universities Human resources management team, and HR practitioners who might use it in reviewing HR related policies also enhance their understanding regarding E-recruitment requirements so they can improve the HR department effectiveness gaps.

\section{LITERATURE REVIEW}

\section{E-Recruitment}

Bodea et al. (2003) stated that the word Electronic-recruitment utilized earliest in the printed articles in the period of the 1990s. In the twentieth century, Electronic-recruitment turned out to be more famous Holm, A. (2014). E-Recruitment comprises of two letters i.e. E and R, E represents Electronic and R indicates Recruitment. Monica (2020) suggest that it is the procedure of staffing the right individuals for the right work moreover e-Recruitment is the most recent technique in which the internet assumes a significant job. Institution's official sites or job boards are incorporated to attracting, finding, evaluating, meeting, and recruiting fresh inhabitants Fick (2020). Electronic-Recruitment is supporting the recruiter to enlist the skilled workforce and assists him in bringing the bigger candidate's pool (Parzinger et al., 2013). Cost reduction and engaging the greater candidate pool are the huge factors of ElectronicRecruitment. Numerous scientists conceded that e-Recruitment is assisting the candidate well as compared to the conventional method of staffing Sills (2014). Shah et al. (2013) revealed that the concept of e-Recruitment isn't yet developed in Pakistan. Innovation is the indication 
of advancement Teo (2012). Fresh technologies are utilized for enhancement in good institutions Jayabalan (2019).

\section{Sources of E-recruitment:}

\section{Role of Institutions Official Websites}

It is showed by Bush et al (2002) that the variation of the official websites as a mediator by institutions has been quicker than some other mediator ever. As per these researchers, the recruitment site's adequacy is impacted by the design of the sites and by the way wherein the information is shown (Banerjee \& Gupta, 2019). Surveys show that institutions increasingly have used official websites that are principally devoted to imparting recruitment information to job-seeker (Cober, Brown \&Levy, 2004). It is additionally apparent that institution's official websites assume a focal function as far as giving an assortment of information about the institution to job-seeker, which can be conveyed in various ways, for example, text, pictures, intelligent connections, and so on (Allen et al., 2012). In the context of official websites, it is analyzed that the Private higher education institutions of Karachi, Pakistan including NUST, IOBM, IBA, AKU, Ziauddin University, Habib University, MAJU, and Barrett Hodgson University, all are providing efficient careers webpage to gain competitive advantage and encourage e-recruitment process for job seekers.

\section{Role of Online Job Boards}

In the middle of 2000, the Job-boards idea was brought into the employment marketplace. Monster.com was the principal recruitment website set up at the same time (Ensher et al, 2003). E-Recruitment is the most recent technique for hiring. The most recent tools for staffing and short-listing that can be utilized are the Internet. It is a genuine hi-tech development for Job hunters and businesses (Parry \& Wilson, 2009). The circumstance of Pakistan isn't distinctive equally similar to other developing nations. Here, the huge institutions additionally pushed on e-Recruitment after the scientific development (Ahmed, Tahir \& Warsi, 2015). Many Jobboards are functioning well in Pakistan, for instance; Jobz.pk, Rozee.pk, Mustakbil.com, Indeed.pk, Naukri.com, and several other social networks like LinkedIn and Facebook. These Job-boards widen the knowledge about employment among job-seekers.

\section{The Usage of the Internet in E-Recruitment}

In Pakistan, since the middle of the 1990s, the access of the Internet has been accessible. The Telecommunication Authority of Pakistan commonly known as "PTA" has begun offering 
access to call set-up across country zones in the year 1995. Consumption of the internet in Pakistan grows rapidly it turned into an essential piece of the country, mostly youthful age. The significant urban communities including Islamabad, Lahore, and Karachi are utilizing a huge chunk of internet access, additionally, service providers producing a huge measure of their income from these urban areas. The conventional recruitment process has been altered by the rise of the Internet. In the previous slight years, the Internet has significantly altered the essence of Human resources recruitment practices and the manners in which institutions consider the hiring purpose particularly in private areas of Pakistan (Malik \& Mujtaba, 2018).

\section{Effectiveness of Human Resource Department via E-recruitment}

HRM comprises of three words, for instance, "Human, Resource, and Management". The word "Human" indicates the qualified staff of an institution, the word "Resource" indicates inadequate availability of resources, and the word Management indicates to strengthen or right allocation of available limited resources (Malik, 2013). The fundamental function of HRM is managing issues identified with workers. Human resources management working began by bringing to individuals, choosing the perfect individuals, and trains them according to the necessity of occupations (Chapman \& Webster, 2003). Additionally, it is examining the competency of the individual concerning the necessity of the employment. HR office likewise measures the performance of the workforce and provides them with the perfect compensation as stated by (Parry \& Tyson, 2008). The commitments of a Head of the human resources department fall into three areas describing/planning the job positions, enrolment tasks, personnel's remuneration, and advantages (Demirkaya et al., 2011). The burden of tasks on HR Managers has diminished as a result of E-Recruitment methods Galanki (2002). Institutions should keep the profile of personnel information and useful data in the database management folder. Such data sets will store data concerning the applicant's contacts, abilities, and referees. (Nguyen \& Teo, 2018) Private sectors play a significant function in the advancement of Pakistan. Workforces (Human Resources) are the base of any institution, so numerous private educational institutions moved their recruitment process on the internet. (Khan et al., 2013). The simple right to use the web to individuals of Pakistan is giving them a chance to apply for diverse positions simultaneously. As stated by (Kazi \& Mannan, 2013), following the fruitful analysis of e-Recruitment in the recent era, institutions of Pakistan are likewise fascinated and want to execute this system. The huge business ratio around 80 to $90 \%$ has their respective official websites and they utilize it for recruitment because of ease and fast reaction stated by (Imam \& Batool, 2013). The larger part of Pakistan particularly the private areas such as Banks, 
Telecom-industries, Global organizations, Educational institutions, NGOs and so many applying the recruitment tactics by electronic means that is Job boards or institution's official sites (William 2021).

\section{Empirical Reviews}

Mindia and Hoque (2018) are conducting an observational analysis on the impact of eRecruitment and the web on the recruitment procedures of multinational businesses in Bangladesh. In the form of questionnaires and interviews, the data sources including primary and secondary were gathered for the analysis. The study centered on 120 respondents with convenience sampling techniques from 30 global corporations. If applied by appropriately qualified recruiters to develop an efficient online recruiting framework, the results revealed that e-recruitment would reward strategic contributions to the enterprise. The investment made by companies in the career pool and on their website should be driven by long-term gains, and online recruiting is now seen by many firms as a successful tool and a growing development in the future.

In this stance, Nasreem (2016) studied technical innovation and development in the job market, which has contributed to recruiting. Specifically, this research statement investigates the impact of e-Recruitment on small and medium-scale IT-based companies mainly located in Lahore. To endorse the report, the researchers used descriptive analysis. Advantages and drawbacks are the characteristics of E-recruitment performance assessment. For small and medium IT firms of Lahore Pakistan, the findings show that the Human resource Managers can focus further on E-recruitment to earn a high return on investment in the long run (Protsch, 2021).

\section{CONCEPTUAL FRAMEWORK}

The Comprehensive inspection of the associated literature facilitates the researcher to extract a Conceptual structure of a research theme. As per various researches, the base of the thesis work is a conceptual framework. It is practically developed; expound the system of connection amongst the variables consider related to the problem statement and recognized through such procedures as meeting, surveillance, the literature review. The below planned theoretical framework reveals the connection between Independent Variable, which is E-Recruitment sources, and the Dependent Variable i.e. is Effectiveness of HRM features. 
Figure 1. Conceptual Framework of Proposed Research Theme

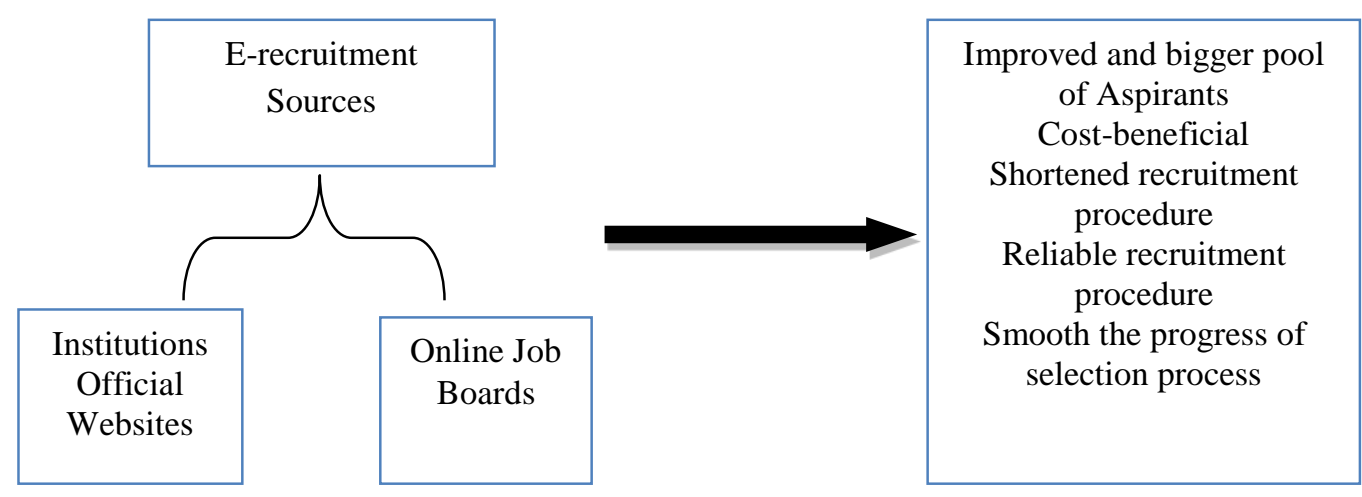

\section{HYPOTHESES DEVELOPMENT}

As per the planned conceptual structure for the proposed research theme, the below-stated are the planned hypotheses:

H1: There is a significant connection between E-Recruitment Sources and the Effectiveness of the HR Dept. in Private HEI's of Karachi, Pakistan.

H2: There is a significant connection between E-Recruitment Sources and the Effectiveness of the HR Dept. in relation to focusing on an improved and bigger pool of aspirants in Private HEI's of Karachi, Pakistan.

H3: There is a significant connection between E-Recruitment Sources and the Effectiveness of the HR Dept. concerning Cost-beneficial associated with recruitment actions in Private HEI's of Karachi, Pakistan.

H4: There is a significant connection between E-Recruitment Sources and the Effectiveness of the HR Dept. concerning Shortened recruitment procedures in Private HEI's of Karachi, Pakistan.

H5: There is a significant connection between E-Recruitment Sources and the Effectiveness of the HR Dept. in providing reliability in the recruitment procedure in Private HEI's of Karachi, Pakistan.

H6: There is a significant connection between E-Recruitment Sources and the Effectiveness of the HR Dept. concerning Smooth the progress of the selection process in Private HEI's of Karachi, Pakistan. 


\section{METHODOLOGY}

\section{Research Design}

The research theme has applied the both "deductive and inductive research approach" which is taken into consideration to deduce and induce the expected hypotheses. The primary data is conducted means the researcher took a quantitative approach and used a self-developed (closeended questionnaire with linear scale options) to collect the data. The Research design that I had selected for the above-stated research topic is mixed-method designs including the "Explanatory and Exploratory research design" due to the above-stated research approach and nature of the research topic. In the Explanatory method, you will measure the relationship between Variables, which is also known as the cause-effect relationship. Similarly, the exploratory method reveals that to expound the different reasons, causes in in-depth.

\section{Sampling Design}

The respondents for this research theme are students who are fresh graduates, doing Masters, or Ph.D. and higher degrees, and HR professionals who belong to different Private HEI's of Karachi, Pakistan. The population is unknown due to the unavailability of the total number of enrolled students and HR professionals in every university make it limited to the approach used for sampling. The researcher used snowball sampling for quantitative data, for that students from many private HEI's of Karachi, Pakistan including HU, ZU, NUST Karachi campus, IOBM, IBA, SZABIST, AKU, MAJU, FAST, SZABIST, IQRA, and so on are selected. And for qualitative data, quota sampling is utilized and targeted employees especially $\mathrm{HR}$ professionals both male and female.

\section{Instrument of Data Collection}

The research study makes use of both quantitative and qualitative approaches; the online survey technique is utilized. The questionnaire on Google survey forms was created. Close-ended questions and linear scale options are used to ask the opinions of respondents via 5 points linear scale options i.e. (Strongly Agree indicates highest agreement point i.e. 5, similarly Agree = 4, Neutral $=3$, Disagree $=2$, and Strongly Disagree $=1$ ). The Likert scale close-ended questionnaire options are applied so that researcher can easily analyze the data on the latest SPSS Software version i.e. 25 to get the expected outcomes. Also, Open-ended structured interviews questionnaire were designed, so that researcher analyze in-depth the perception of HR professionals on a given topic. 


\section{Statistical Analysis}

To measures the quantitative data collection, many statistical tools are utilized which include descriptive statistics, reliability test, KMO and Bartlett's Test of Sphericity, Pearson Correlation, and multiple regression. To measure qualitative data, the transcription technique was utilized.

\section{RESULTS AND DISCUSSION}

\section{Quantitative Descriptive Statistics}

Age: The descriptive statistics of age indicate the variation of 250 respondents ranging from 20-51 and above years. The majority of respondents are of the age bracket 20-25 years with the frequency of 167 respondents, which is $66.8 \%$ of the total sample. The frequency of age bracket $26-35$ years is 51 respondents, which is $20.4 \%$ of the total sample. 22 respondents are of age bracket $36-50$ years, which is $8.8 \%$ of the total sample and 10 respondents are of age bracket 51 and above years which is $4 \%$ of the total sample size.

Gender: The distribution of respondents among gender is as follow. The Male respondents were 130 among 250, which is $52 \%$ of the total sample, and the Female respondents were 120 among 250 , which is $48 \%$ of the total sample size.

Qualification: The descriptive statistics of the qualification level of the respondents indicate the variation of 250 respondents ranging from Fresh graduates to Postdoctoral degrees. The greater parts of respondents are lies in the Fresh graduates with the frequency of 142 respondents, which is $56.8 \%$ of the total sample. The frequency of Master's (MA, M.Sc.) is 66 respondents, which is $26.4 \%$ of the total sample size. 22 respondents are lies in the Postgraduate (M.Phil., Ph.D.) qualification bracket, which is $8.8 \%$ of the total sample and 20 respondents are lies in the Postdoctoral degree qualification bracket which is $8 \%$ of the total sample size.

Employment Status: The graphical data of the Employment status of 250 respondents indicate that the majority of respondents have less experience i.e., 0-3 years, with the frequency of 152 respondents, which is $60.8 \%$ of the total sample. It reveals that many respondents are fresh graduates and have only internships or less experience of the job. The frequency of respondents who has 3-5 years of employment experience is 63 , which is $25.2 \%$ of the total sample. 24 respondents have 5-10 years of job experience, which is $9.6 \%$ of the total sample and 11 respondents have more than 10 years of job experience which is $4.4 \%$ of the total sample size. It also shows a minor number of respondents who have greater experience of the corporate world. 
Respondent's Institute Name: The targeted Private HEI's of Karachi, Pakistan for the analysis was Habib University, AKU, ZU, IBA Karachi, IOBM Karachi, Salim Habib University Karachi is formerly known as BHU, NUST Karachi Campus, MAJU, FASTNUCES, SZABIST, IQRA, and Other institutions which includes (Baqai Medical University, Indus University, DHA Suffa, Greenwich and PAF-KIET). The frequency distribution of respondents among the 12 private HEI's is as follows. The respondents belong to HU are 26 from 250 which is $10.4 \%$ of the total sample. The respondents from the AKU are 25 from 250 , which is $10 \%$ of the total sample. The respondents from $\mathrm{ZU}$ are 23 from 250 , which is $9.2 \%$ of the total sample. The respondents belong to IBA Karachi are 16 from 250, which is $6.4 \%$ of the total sample. The respondents belong to IOBM Karachi are 20 from 250, which is $8 \%$ of the total sample. The respondents belong to BHU are 15 from 250, which is $6 \%$ of the total sample. The respondents from NUST Karachi Campus are 13 from 250, which is $5.2 \%$ of the total sample. The respondents belonging to MAJU are 11 from 250 , which is $4.4 \%$ of the total sample. The respondents who belong to FAST-NUCES Karachi are 12 from 250, which is 4.8 $\%$ of the total sample. The majority of respondents belong to SZABIST Karachi i.e. 35 from 250 , which is $14 \%$ of the total sample. The highest ratio of respondents belongs to IQRA University after SZABIST is 29 from 250 , which is $11.6 \%$ of the total sample and lastly all other respondents belong to the other category is 25 from 250 , which is $10 \%$ of the total sample size.

\section{Reliability Test}

Table 1. Reliability Statistics

\begin{tabular}{cc}
\hline \multicolumn{2}{c}{ Reliability Statistics } \\
\hline Cronbach's Alpha & N of Items \\
.909 & 27 \\
\hline
\end{tabular}

The dependability of the questionnaire was ensured by pre-testing. The scholar gave questionnaires to the fresh graduates, masters, Ph.D. holders, and others from selected private HEI's of Karachi, Pakistan for pre-testing. The result of the test was analyzed using SPSS version 25 and the whole result of 27 items fell at 0.909 , It is a better reliability score due to the thumb rule of Cronbach's Alpha Base that is reliability value should be greater than 0.70 is to accepted and reliable. 


\section{KMO Test and Bartlett's Test of Sphericity}

Table 2. KMO and Bartlett's Test

\begin{tabular}{lcc}
\hline \multicolumn{3}{c}{ KMO and Bartlett's Test } \\
\hline Kaiser-Meyer-Olkin Measure of Sampling Adequacy. & .946 \\
Bartlett's Test of Sphericity & Approx. Chi-Square & 5828.661 \\
& Df & 231 \\
& Sig. & .000 \\
\hline
\end{tabular}

According to the thumb rule of KMO, the results table of KMO reveals that the value of KMO i.e. 946 lies in the excellent category result as it exceeds the value of 0.8. It clarifies that this study could conduct a factor analysis. So, the results reveal that sampling is adequate. In KMO the result near to value zero, in inadequate for factor analysis. Though Bartlett's test of Sphericity indicates a value of .000 which is below .005 , it senses that factors that form the variable are acceptable. The results reveal that there is no high correlation or coefficient between the variables.

According to the strength of correlation table (3) below, the researcher can easily interpret the results of correlation; therefore, the above table shows that the correlation between ERecruitment and the Effectiveness of the HR department is 0.823 , which proposes that ERecruitment has a Strong positive relationship with dependent variable i.e. Effectiveness of HR department. The correlation between the variable Institutions Official website and Effectiveness of HR department is 0.840, which suggests that the Institutions Official website has also a strong positive relationship with the dependent variable. The correlation between Online Job boards and the Effectiveness of the HR department is 0.752, which suggests that the Online Job boards have also a strong positive relationship with the Effectiveness of the HR department.

The results reveal that all the independent variables i.e. E-Recruitment and Sources of ERecruitment which include (Institution's official websites and Online Job boards) have a strong positive relationship with the dependent variable i.e. the Effectiveness of the HR department. It means that all independent variables increase the level of effectiveness of HR Dept. in the Private HEI's of Karachi, Pakistan at a 5\% level hence the alternative hypothesis is accepted. 
Table 3. Pearson Correlation Coefficient Statistics

\begin{tabular}{lllll}
\hline & E-Recruitment & $\begin{array}{c}\text { Institutions Official } \\
\text { Website }\end{array}$ & $\begin{array}{c}\text { Online Job } \\
\text { Boards }\end{array}$ & E_HR_Dept. \\
\hline E-Recruitment & 1 & $.863^{* *}$ & $.630^{* *}$ & $.823^{* *}$ \\
\hline Institutions_Official Website & $.863 * *$ & 1 & $.659^{* *}$ & $.840^{* *}$ \\
\hline Online_JB & & & 1 & $.752^{* *}$ \\
\hline E_HR_Dept & $.630^{* *}$ & $.659^{* *}$ & $.752^{* *}$ & 1 \\
\hline$* *$ Correlation is significant at the 0.01 level (2-tailed). & $.840^{* *}$ & \\
\hline
\end{tabular}

Model Summary

Table 4. Model Summary

\section{Model Summary}

\begin{tabular}{|c|c|c|c|c|c|c|c|c|c|}
\hline \multirow[t]{2}{*}{ Model } & \multirow[t]{2}{*}{$\mathrm{R}$} & \multirow{2}{*}{$\begin{array}{c}\mathrm{R} \\
\text { Square }\end{array}$} & \multirow{2}{*}{$\begin{array}{l}\text { Adjusted R } \\
\text { Square }\end{array}$} & \multirow{2}{*}{$\begin{array}{l}\text { Std. Error } \\
\text { of the } \\
\text { Estimate }\end{array}$} & \multicolumn{5}{|c|}{ Change Statistics } \\
\hline & & & & & $\begin{array}{l}\text { R Square } \\
\text { Change }\end{array}$ & $\begin{array}{c}\mathrm{F} \\
\text { Change }\end{array}$ & df1 & df 2 & $\begin{array}{l}\text { Sig. F } \\
\text { Change }\end{array}$ \\
\hline 1 & $\begin{array}{r}.894 \\
\mathrm{a}\end{array}$ & .799 & .796 & 2.86081 & .799 & $\begin{array}{r}325.72 \\
6\end{array}$ & 3 & 246 & .000 \\
\hline
\end{tabular}

a. Predictors: (Constant), Online_Job_Boards, Electronic_Recruitment, Institutions_Official_Websites

The above table "Model Summary" shows that the R. square of predictors (E-Recruitment, Institution's official websites, and Online job boards) and the response (Effectiveness of HR department) is 0.799 or $79.9 \%$ and the adjusted R. square is 0.796 or $79.6 \%$ at the significance level of 0.05 or $95 \%$ of the confidence interval. R-Value also shows the overall fitness of the model.

Table 5. ANOVA

\begin{tabular}{llrrrrr}
\hline \multicolumn{7}{c}{ ANOVA } \\
Model & & Sum of Squares & df & Mean Square & F & Sig. \\
\hline \multirow{2}{*}{$\mathbf{1}$} & Regression & 7997.458 & 3 & 2665.819 & 325.726 & $.000^{\mathrm{b}}$ \\
\cline { 2 - 8 } & Residual & 2013.326 & 246 & 8.184 & & \\
\cline { 2 - 8 } & Total & 10010.784 & 249 & & & \\
\hline
\end{tabular}

a. Dependent Variable: Effectivenessof_HR_Department

b. Predictors: (Constant), Online_Job_Boards, Electronic_Recruitment, Institutions_Official_Websites

The above table (4) is the Analysis of Variance (ANOVA) of multiple regressions, which stated that the P-value (Significance Value) connected with the F value i.e. 325.726, is very small (0.0000). The above result reveals that the Sig. value is less than 0.05 , and if the value is smaller so, it means that the independent variables (E-Recruitment, Institution's official website, and 
Online Job boards) consistently predict the dependent variable i.e. Effectiveness of Human Resource Department.

\section{Coefficients of Variables}

Table 6. Multiple regression

\begin{tabular}{|c|c|c|c|c|c|c|}
\hline \multicolumn{7}{|c|}{ Coefficients $^{\mathrm{a}}$} \\
\hline \multirow{2}{*}{\multicolumn{2}{|c|}{ Model }} & \multicolumn{2}{|c|}{ Unstandardized Coefficients } & \multirow{2}{*}{$\begin{array}{l}\text { Standardized } \\
\text { Coefficients }\end{array}$} & \multirow[t]{2}{*}{$\mathrm{t}$} & \multirow[t]{2}{*}{ Sig. } \\
\hline & & B & Std. Error & & & \\
\hline \multirow[t]{4}{*}{1} & (Constant) & 2.438 & .844 & & 2.889 & .004 \\
\hline & Electronic_Recruitment & .416 & .077 & .309 & 5.385 & .000 \\
\hline & $\begin{array}{l}\text { Institutions_Official_Web } \\
\text { sites }\end{array}$ & .494 & .080 & .364 & 6.149 & .000 \\
\hline & Online_Job_Boards & .528 & .064 & .317 & 8.232 & .000 \\
\hline
\end{tabular}

The unstandardized beta of E-Recruitment with the value of 0.416 concludes that with one percent change in E-Recruitment level brings a $41.6 \%$ change in effectiveness level of the HR department at Private HEI's. The unstandardized beta of Institutions Official Websites with the value of 0.494 concludes that a one percent change in Institutions Official Websites brings a 49.4\% change in the level of effectiveness of HR department at Private HEI's. The unstandardized beta of Online Job boards with the value of 0.528 concludes that with one percent change in Online Job boards brings a 52.8\% change in the level of effectiveness of the HR department at Private HEI's. The standardized beta of E-Recruitment with the value of 0.309 concludes that with one percent change in the Effectiveness of the HR department brings a $30.9 \%$ change in E-Recruitment. The standardized beta of institutions official websites with the value of 0.364 concludes that with one percent change in the effectiveness of the HR department brings a $36.4 \%$ change in institutions official websites. The standardized beta of Online Job boards with the value of 0.317 concludes that a one percent change in the Effectiveness of the HR department brings a $31.7 \%$ change in Online Job boards and the tvalue of all independent variables is larger than +2 . The greater the $t$-value the higher the confidence we have in coefficient as a predictor. It means the variables have strong reliability. It also discloses that there is a significant difference in the variables.

\section{Hypotheses Testing}

$\boldsymbol{H 1}$ - The Pearson correlation table discloses that there is a strong positive relationship between e-Recruitment sources and the Effectiveness of the HR Dept. in Private HEI's of Karachi, Pakistan. Hence $\mathrm{H} 1$ is accepted at the $5 \%$ significance level. All Others $\mathrm{H} 2, \mathrm{H} 3, \mathrm{H} 4, \mathrm{H} 5$, and 
H6 are linked with H1. Hence all are accepted. The multiple regression table also revealed that the predictor variables (E-Recruitment, Institution's official website, and Online Job boards) have a multiplier effect with dependent variable i.e. Effectiveness of HR department. All the variables have a higher $\mathrm{t}$-value than +2 . And both independent and dependent variables are accepted at $5 \%$ of the significance level. H1, H2, H3, H4, H5, H6 = All the Alternative Hypotheses are accepted.

\section{Descriptive Profile of respondents (Interviewees)}

\begin{tabular}{lllll}
\hline \multicolumn{2}{l}{ Table 6 - Respondent's Profiles (Interviewees) } \\
\hline & Present Designation/ Institute Name & Job Experience & Age Bracket & Gender \\
\hline 1. & Sr. Manager /IU & 5-10 years & $26-35$ years & Female \\
\hline 2. & Sr. HR Officer /HU & 0-3years & $20-25$ years & Female \\
\hline 3. & Assistant Manager HR /HU & 0-3years & $26-35$ years & Male \\
\hline 4. & HR Executive /IBA & 5-10years & $26-35$ years & Male \\
\hline 5. & HR Executive /ZU & 0-3years & $20-25$ years & Female \\
\hline 6. & Specialist of Learning and OD /AKU & 3-5years & $26-35$ years & Female \\
\hline
\end{tabular}

\section{Interview Results Conclusion with the help of Research Objectives}

To determine the level of effectiveness of the Human Resources Department in terms of ERecruitment in Private HEI's of Karachi, Pakistan. The researcher has accomplished this objective, as it revealed by interviews that the HR department of Private HEI's of Karachi including Habib University, IBA, AKU, ZU, and IQRA University has effectively led the entire E-recruitment process. Many of the respondents informed that 60-75\%, E-recruitment increases the level of effectiveness of the Human resource department. The rest of $25 \%$ many private HEI's are in trial and error, and they are striving to fill that gap. They also told that if an institution has a strong working team particularly IT Team (They have technical minds to assist the E-recruitment system) and a Strong placement department team (They are effectively executing the recruitment process) then institutions will conceivably find the effectiveness in the HR Department. To identify measures that the HR management has put in place to tackle the E-recruitment challenges in Private HEI's of Karachi, Pakistan.

The interview results stated that many private HEI's of Karachi, Pakistan utilizing several measures to tackle the E-recruitment challenges and make the recruitment process more convenient. Such as Habib University frequently makes use of the Official career webpage, LinkedIn account, IBA, and LMS Alumni portal and selects consulting firms like learning 
minds to find the 1st objective recruitment i.e. attracting the best-fit applicants with the job. Similarly, IBA has a strong IBA job portal and Alumni network. Also, they organized Google drive, excel sheets, and ERP software's to make the database system efficient and take Erecruitment to the next level. To determine the relationship between E-Recruitment and Human Resources Department in Private HEI's of Karachi, Pakistan. This objective is also satisfied. The qualitative and quantitative results indicate that there is a significant positive connection among the independent variables i.e. E-Recruitment Sources (Institutions Official Websites and Online Job boards) and the dependent variable i.e. effectiveness of the Human resources department in Private HEI's of Karachi, Pakistan.

\section{CONCLUSION}

To conclude this whole research study, the researcher accomplished all the planned hypotheses as per the analyzed data. The Pearson correlation table discloses that there is a strong positive relationship between e-Recruitment sources and the Effectiveness of the HR Dept. in Private HEI's of Karachi, Pakistan. Hence H1 is accepted at the 5\% significance level. All Others H2, H3, H4, H5, and H6 are linked with H1. Hence all are accepted and it is also evidenced from interviews that Electronic has improved a bigger pool of aspirants means it has greater geographical reach. It is Cost-beneficial, and Shortened recruitment procedures mean it consumes less time. E-recruitment is providing reliability in the recruitment procedure. It also smoothens the progress of the selection process. Therefore, all the elements have a significant positive relationship with E-recruitment. The multiple regression table also revealed that the predictor variables (E-Recruitment, Institution's official website, and Online Job boards) have a multiplier effect with dependent variable i.e. Effectiveness of HR department. All the variables have a higher $t$-value than +2 . And both independent and dependent variables are accepted at $5 \%$ of the significance level. The reliability score of the questionnaire of quantitative data is also accepted at the value of .909 and the KMO test value i.e. .946 which exceeds the 0.5 value. So it is proved that this study is suitable for factor analysis, and Bartlett's test of sphericity indicates the value i.e. .000 in the results which is less than .005 means factors the form a variable is satisfactory. Above all, the stated results indicate that this study is acceptable. In the end, the researcher is happy to participate in such a demanding research study that is focused on brandishing our observational skills and analytical skills. Though the researcher faced some discrepancies there was no match to what the researcher has learned. 


\section{LIMITATIONS OF THE STUDY}

The limitations of the study included but were not limited to the following; fresh graduates were selected only from private universities of Karachi Pakistan narrowing the location of study; the small sample size was selected and analyzed through online mode for convenience and COVID-19 crises; only private HEI's from Karachi were targeted whereas public HEIs were excluded. Moreover, the authors understand that sending the questionnaire through Google Docs form might not be the only best method to conduct research. Thus further research studies may overcome the limitations mentioned above for better, accurate and generalized results.

\section{RECOMMENDATIONS}

Researchers recommended that to test the other groups with more samples and concentrating on the other regions except for Private HEI's Karachi. Such kinds of research studies should use a qualitative approach instead of quantitative for an in-depth investigation. A mix of both is also a good solution. Interviews conducted through physical presence are a more convenient approach. An equitable check and balance system should be put in place so that the performances of all departments such as the HR department should be reviewed periodically their management techniques should be scrutinized for an efficient learning environment. Through this study, all the stakeholders involved in Private HEI's (President / HR team and jobseekers) should use these findings, for valuable facility approaches to the E-recruitment process.

\section{AREA FOR FUTURE RESEARCH}

An individual or any institution wishing further research in the subject "E-recruitment" can explore the Public category HEI's, How it is a success factor for Jobseekers, Private Colleges and Schools recruitment system instead of Effectiveness of Private HEI's to get a much clearer idea. The findings can assist University management, HR departments, and Jobseekers especially those who are willing to serve in educational institutions to understand the indicators of E-recruitment and how it affects the HR department so they make it better for the future.

\section{Acknowledgement:}

We acknowledge the precious time given by all interviewees and providing us with their responses.

\section{Author(s) Contribution:}

All authors contributed equally. 


\section{REFERENCES}

Ahmed, S., Tahir, H., \& Warsi, S. W. (2015). E -Recruitment Transforming the Dimensions of Online Job Seeking: A case of Pakistan. International Journal of Human Resource Studies, 5(1), 96. https://doi.org/10.5296/ijhrs.v5i1.6161

Allen, D. G., Biggane, J. E., Pitts, M., Otondo, R., \& van Scotter, J. (2012). Reactions to Recruitment Web Sites: Visual and Verbal Attention, Attraction, and Intentions to Pursue Employment. Journal of Business and Psychology, 28(3), 263-285. https://doi.org/10.1007/s10869-012-9281-6

Amin, M. A., Orife, J. N., \& Wibowo, K. (2002). The legality of keyword search as a personnel selection tool. Employee Relations, 24(5), 516-522. https://doi.org/10.1108/01425450210443285.

Armstrong, M. (2010), Armstrong's Essential Human Resource Management Practice: A Guide to People Management, 11th edition. London: Kogan Page Publishers.

Attaa, Aamir (2009), Pakistani Internet users to hit 22 million mark in 2013. Pro Pakistan. Retrieved on 12 August 2009 from http://propakistani.pk/2009/08/12/pakistaniinternet-users-to-hit-22-millionmark-in-2013/

Banerjee, P., \& Gupta, R. (2019). Talent Attraction through Online Recruitment Websites: Application of Web 2.0 Technologies. Australasian Journal of Information Systems, 23. https://doi.org/10.3127/ajis.v23i0.1762

Bodea, C., Bodea, V., \& Zsolt, M. (2003). Human Resource Management in the Internet Age: e-Recruitment and e-Selection Methods. Economy Informatics, 3(3), 5-7.

Breaugh, J. A., \& Starke, M. (2000). Research on Employee Recruitment: So Many Studies, So Many Remaining Questions. Journal of Management, 26(3), 405-434. https://doi.org/10.1177/014920630002600303

Bush, V. D., \& Gilbert, F. W. (2002). The Web as a Medium: An Exploratory Comparison of Internet Users versus Newspaper Readers. Journal of Marketing Theory and Practice, 10(1), 1-10. https://doi.org/10.1080/10696679.2002.11501905

Chapman, D., \& Webster, J. (2003). The Use of Technologies in Recruiting, Screening, and Selection Processes for Candidates", International Journal of Selection and Assessment, 11(2/3), 113-120. https://doi.org/10.1111/1468-2389.00234

CIPD. Resourcing and Talent Planning. CIPD Survey Report, (2015). Available from: https://www.cipd.co.uk/hr-resources/survey-reports/resourcing-talent-planning2015.aspx.

Cober, R, T., Brown, D. J., Levy, P. E. (2004a), 'Form, content, and function: an avaluativr methodology for corporate employment web sites,' Human Resource Management. 43(2/3), 201-218. doi: 10.1002/hrm.20015. 
Compton, R. L., W. J. Morrissey, A. R. Nankervis, and B. Morrissey (2009), Effective Recruitment and Selection Practices. CCH Australia Limited.

Demirkaya, H., Özcüre, G., \& Eryiğit, N. (2011). An application on the impacts of human resource management in technology management of the companies. Procedia-Social and Behavioral Sciences, 24, 474-486. https://doi.org/10.1016/j.sbspro.2011.09.045

DeSanctis, G. (1986), Human resource information systems: A current assessment. MIS Quarterly, Volume 10(1), pp. 15-27. http://dx.doi.org/10.2307/248875

Ensher, E. A., Nielson, T. R., \& Grant, V. E. (2003). Tales from the hiring line: effects of the internet and technology on HR processes. Organizational Dynamics, 31(3), 224-244. https://doi.org/10.1016/S0090-2616(02)00111-0

Fick, L., Palmisano, K., \& Solik, M. (2020). Residency Program Social Media Accounts and Recruitment - A Qualitative Quality Improvement Project. MedEdPublish, 9(1). https://doi.org/10.15694/mep.2020.000203.1

Galanaki, E. (2002). The Decision to recruit Online: A Descriptive Study, Career International Development, 7(4), 243-251. https://doi.org/10.1108/13620430210431325

Holm, A. (2014). Institutional context and e-recruitment practices of Danish organizations. Employee Relations, 36(4), 432-455. https://doi.org/10.1108/ER-07-2013-0088.

Imam, H., \& Batool, S. N. (2013). Organizational Perception Regarding Specific Information about Job and Organization: An Approach to E-Recruitment. International SAMANM Journal of Business and Social Sciences, 1(1), 26-33.

Imam, S., \& Javed, T. (2019). Job Security, Organizational Support and Employee Performance: Mediating role of Employee Satisfaction in Medical Sector of Pakistan. International Journal of Academic Research in Business and Social Sciences, 9(3). https://doi.org/10.6007/ijarbss/v9-i3/5793

Jayabalan N, et al, (2019), E-recruitment Technology Adoption among Generation Z JobSeekers. (2019). International Journal of Engineering and Advanced Technology, 9(2), 1880-1888. https://doi.org/10.35940/ijeat.b3065.129219

Kapse, Avinash S., Vishal S. Patil, and Nickil V. Patil (2012), E-recruitment. International Journal of Engineering and Advanced Technology (IJEAT), Volume 1(4), pp. 82-86.

Kazi, A. K., \& Mannan, M. A. (2013). Factors affecting adoption of mobile banking in Pakistan. International Journal of Research in Business and Social Science (21474478), 2(3), 54-61. https://doi.org/10.20525/ijrbs.v2i3.73

Khan, NR, Awang, M., \& Ghouri, AM (2013). Impact of E-Recruitment and Job-Seekers Perception on Intention to Pursue Jobs. Management \& Marketing, 11(1), 47-57.

Malik, M. S., \& Mujtaba, M. A. U. (2018). Impact of E-Recruitment on Effectiveness of HR Department in Private Sector of Pakistan. International Journal of Human Resource Studies, 8(2), 80. https://doi.org/10.5296/ijhrs.v8i2.12869 
Malik, Z. (2013). The Role of E-recruitment Towards Attraction of Workforce: A Case of Telecom Sector Organization. Abasyn University Journal of Social Sciences, 6(1).

Mindia, P. M., \& Hoque, M. K. (2018). Effects of E-recruitment and internet on recruitment process: An Empirical study on Multinational companies of Bangladesh. International Journal of Scientific Research and Management, 6(01). https://doi.org/10.18535/ijsrm/v6i1.em01

Monica, B. (2020), Perception of job seekers towards innovative e-recruitment. (2021). Journal of Contemporary Issues in Business and Government, 26(02). https://doi.org/10.47750/cibg.2020.26.02.058

Nasreem, S., Hassan, M., \& Khan, T. A. (2016). Effectiveness of e-recruitment in small and medium enterprises of IT industry of Lahore (Pakistan). Pakistan Economic and Social Review, 54(1), 143-164.

Nguyen, D. T., \& Teo, S. T. (2018). HR orientations and HR department effectiveness in Vietnam. Personnel Review, 47(5), 1043-1061. https://doi.org/10.1108/pr-03-20170074

Parry, E., \& Tyson, S. (2008). An analysis of the use and success of online recruitment methods in the UK. Human Resource Management Journal, 18(3), 257-274. https://doi.org/10.1111/j.1748-8583.2008.00070.x

Parry, E., \& Wilson, H. (2009). Factors Influencing the Adoption of Online Recruitment, Personnel Review, 38(6), 655-673. https://doi.org/10.1108/00483480910992265

Parzinger, M. J., Ward, S. G., \& Langford, M. (2013). Web Recruitment: Impact of Aesthetics and Playfulness on User's Initial Affective Reactions as it Relates to Applicant Attraction. In Proceedings of the Conference for Information Systems Applied Research ISSN (Vol. 2167, p. 1508).

Protsch, P. (2021). Employers' recruitment contexts and hiring preferences in the German youth labor market. Research in Social Stratification and Mobility, 73, 100608. https://doi.org/10.1016/j.rssm.2021.100608

Shah, G. U. D., Bhatti, M. N., Iftikhar, M., Qureshi, M. I., \& Zaman, K. (2013). Implementation of the technology acceptance model in an e-learning environment in rural and urban areas of Pakistan. World Applied Sciences Journal, 27(11), 1495-1507.

Sills, M. (2014). E-recruitment: A comparison with traditional recruitment and the influences of social media: A qualitative and quantitative review.

Teo, T. (2012). Examining the intention to use technology among pre-service teachers: an integration of the Technology Acceptance Model and Theory of Planned Behavior. Interactive Learning Environments, 20(1), 3-18. https://doi.org/10.1080/10494821003714632 
Williams, P., McDonald, P., \& Mayes, R. (2021). Recruitment in the gig economy: attraction and selection on digital platforms. The International Journal of Human Resource Management, 1-27. https://doi.org/10.1080/09585192.2020.1867613

\section{Interview References:}

Senior Manager at placement department of Iqra University, email id: mufarrah@iqra.edu.pk Senior HR Officer at Habib University, email id: ayman.sattar@habib.edu.pk

Assistant HR Manager at Habib University, email id: zunair.ejaz@ habib.edu.pk

HR Executive at IBA Karachi, email id: afida@iba.edu.pk

HR Executive at Ziauddin University, email id: sanya.salman@zu.edu.pk

HR Officer / Learning and OD Specialist, email id: serena.anwar@aku.edu 